\title{
Influence of curing procedures and porosity in the flexural resistance of concretes for paving
}

\section{Influência do método de cura e da porosidade na resistência à tração na flexão de concretos para pavimentação}
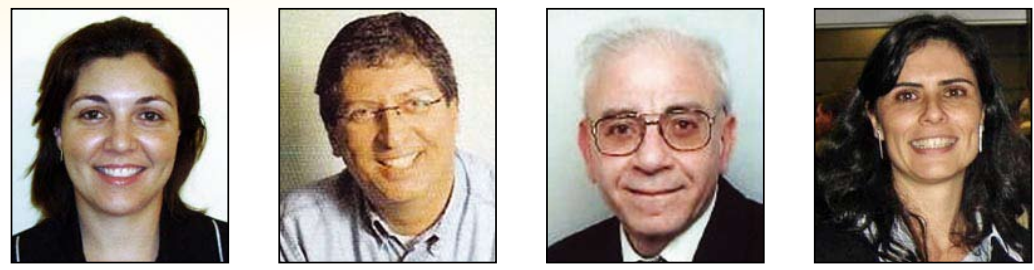

T.C. CERVO a tcervo@terra.com.br

J.T. BALBO b

jotbalbo@usp.br

M. BADAWY c badawy@bluenet.ch

A.A. SEVERI aseveri@gmail.com

\begin{abstract}
Flexural strength of high performance concrete submitted to several non-standard curing conditions was evaluated through bending tests on beams in order to allow comparisons among different curing procedures. The moist curing process resulted more effective than curing by chemical products leading to membrane formation over concrete surface; moreover, flexural strength of high strength concrete was increased when saturated specimens were tested, whereas conventional concrete flexural strength decreased when submitted to the same conditions. Such results were explained on the basis of concrete porosity with the support of air permeability tests. Results explained differences between the behavior of conventional and high strength concrete when water fills the specimen pores. As recommendation, high strength concrete specimens shall not be tested in bending in saturated condition under the risk of overestimation of flexural resistance.
\end{abstract}

Keywords: flexural strength, curing, porosity.

\section{Resumo}

Um concreto de elevada resistência recebeu diferentes tipos de cura em laboratório e testes de resistência à tração na flexão permitiram comparar os resultados devidos aos diferentes processos de cura. A cura úmida resultou bem mais eficiente que a cura com aspersão de produto químico formando membrane sobre a superfície do concreto.; mais importante, a resistência à flexão dos concretos de elevada resistência aumentou quando o corpo de prova estava saturado enquanto que para concretos convencionais de pavimentação essa resistência diminuiu com a saturação das amostras. Com base em testes de permeabilidade ao ar para ambos os concretos, buscou-se explicar a natureza do fenômeno encontrado, considerando as gritantes diferenças na estrutura de poros de ambos os concretos. Como principal recomendação, a medida de resistência à tração na flexão para concretos de elevada resistência não deve ser realizada com amostras saturadas dados os resultados irreais encontrados

Palavras-chave: resistência à tração na flexão; cura; porosidade.

Universidade Federal de Santa Maria, tcervo@terra.com.br, Av. Roraima, 1000, Camobi, CT, Dpto de Transportes, 97105-900, Santa Maria, RS, Brasil Universidade de São Paulo, Epusp, jotbalbo@usp.br, Av. Prof. Almeida Prado 82, Cidade Universitária, 05508-900, São Paulo, Brasil

TFB A.G., badawy@bluenet.ch, Lindenstrasse 10,CH-5103,Wildegg, Suiça

ECOWORLD, aseveri@gmail.com, Rua Jacurici 166, 01453-030, São Paulo, Brasil 


\section{Introduction - Motivation and Aims}

Curing of concrete and its saw cutting in pavements are the more important issues to ensure the accomplishment of the mixture proportioning design in terms of strength and durability. Although concrete pavements, after they have been laid and finished, are subjected to huge variations in environmental conditions like air temperature, solar radiation, wind and moisture, as well as loss of moisture due to contact with their supporting base in construction sites, it is still a common practice to immerse molded specimens of fresh concrete in water tanks up to the day of the strength test as a quality control procedure.

Concerns related to concrete curing became more intense after the advent of high strength concrete for buildings, with several investigations about how curing affects compressive strength since in this case it is common to use low w/c ratio $(<0.4)$, early strength cements and addition of fines like silica fume or reactive powder. A former investigation concluded that cylindrical specimens for compressive tests apparently yielded better results when kept in water immersion for a shorter period [1].

Tests under field conditions and using PVC film as membrane for protection of specimens against evaporation showed, after a oneyear investigation, that water immersion and plastic membrane result in similar permeability [2]. Field conditions for curing implied greater permeability, suggesting different results for material structure due to different curing procedures. Saturation and drying effects on strength with the using of an oven resulted in decreasing strength when the conventional concrete specimen was kept in a tank up to the day of the test [3].

There are arguments in favor of curing concrete specimens in moist chamber (with water steam) or by means of wrapping the specimens with plastic film to avoid water loss. Even shortening the curing period is reasonable when compressive strength is not the key factor [1]. However, flexural strength is the most impor- tant characteristic of the concrete mixture for plain jointed concrete pavements due to their influence on early shrinkage control and fatigue life-span. This fact assumes paramount significance when a high strength concrete is desirable for the task of opening pavement to traffic as early as possible and for pavement solutions with thin concrete slabs.

The primary target of the investigation was evaluating the curing effects on flexural strength of concretes and some unexpected results are discussed within this paper. Prismatic specimens of two types of concrete, conventional concrete (CC) and high strength concrete (HSC) were molded. Other methods different than traditional curing were considered, such as using specimens wrapped in PVC film or by spreading chemical curing membrane over specimen surfaces kept in their molds. The achieved results are interpreted on the basis of permeability and porosity tests for the considered concretes.

\section{Materials and Experimental Procedures}

Two types of paving concretes were prepared for the study: one conventional concrete (CC) using cement type CP II E 40 and one high strength concrete (HSC) using early strength cement type $\mathrm{CP}$ V ARI RS; strengths for the mixtures at 28 days were $4.9 \mathrm{~N} / \mathrm{mm}^{2}$ and $6 \mathrm{~N} / \mathrm{mm}^{2}$. Tables 1 presents the mixture design for both concretes used in this investigation. Specimens for measuring flexural strengths were prepared using $100 \times 100 \times 400 \mathrm{~mm}$ prismatic molds, and vibration of fresh concrete in the mold was done on a vibrating table during $30 \mathrm{~s}$. Specimens were removed from molds after 24 to 36 hours to accomplish the resting curing period.

Specimens of HSC were kept in several curing methods up to 7 , 28, 56 and 91 days before flexural strength tests. Curing methods used are fully detailed in Table 2 . Conventional concrete was tested at 28 and 365 days, and the curing procedure followed common patterns employed in highway construction: specimens

\section{Table 1 - High strength (HSC) and conventional (CC) concrete mix proportions}

\begin{tabular}{|ccc|}
\hline Materials and properties & HSC & CC \\
W/c ratio & 0.37 & 0.55 \\
Early strength Portland cement $\left(\mathrm{kg} / \mathrm{m}^{3}\right)$ & 440 & - \\
Ordinary Portland cement $\left(\mathrm{kg} / \mathrm{m}^{3}\right)$ & & 328 \\
Silica Fume $\left(\mathrm{kg} / \mathrm{m}^{3}\right)$ & 44 & - \\
Sand $\left(\mathrm{kg} / \mathrm{m}^{3}\right)$ & 493 & 691 \\
Fineness module & 1.14 & 1.72 \\
Maximum grain diameter $(\mathrm{mm})$ & 1.2 & 2.4 \\
Medium crushed stone $\left(\mathrm{kg} / \mathrm{m}^{3}\right)$ & 1.194 & 483 \\
Fineness module & 6.71 & 6.66 \\
Maximum grain diameter $(\mathrm{mm})$ & 19 & 25 \\
Plasticizer $\left(\mathrm{L} / \mathrm{m}^{3}\right)$ & 1.65 & 1.65 \\
Super Plasticizer $\left(\mathrm{L} / \mathrm{m}^{3}\right)$ & 3.85 & - \\
Entrained air $(\%)$ & 4 & 2.6 \\
Slump $(\mathrm{mm})$ & 80 & 65 \\
\hline
\end{tabular}




\section{Table 2 - Curing procedures employed for HSC}

\begin{tabular}{|c|c|c|c|c|c|c|c|}
\hline \multirow{2}{*}{ Curing Method } & \multicolumn{6}{|c|}{ Procedures (in days) } & \multirow{3}{*}{$\begin{array}{l}\text { (i) Immersion in water } \\
\text { tank (in days, at } \\
\text { constant } 20^{\circ} \mathrm{C} \text { ); }\end{array}$} \\
\hline & I & II & III & IV & V & VI & \\
\hline$A$ & 7 & No & No & No & No & 7 & \\
\hline B & 7 & No & 21 & No & No & 28 & \multirow{3}{*}{$\begin{array}{l}\text { (II) Moisture chamber } \\
\text { (in I days, at } \\
\text { constant 100\% } \\
\text { moisture); }\end{array}$} \\
\hline C & 28 & No & No & No & No & 28 & \\
\hline $\mathrm{D}$ & No & 7 & No & Yes & No & 7 & \\
\hline E & No & 7 & 21 & Yes & No & 28 & \multirow{3}{*}{$\begin{array}{l}\text { (III) Days exposed in } \\
\text { laboratory before } \\
\text { tests (at constant } \\
25^{\circ} \text { C); }\end{array}$} \\
\hline$F$ & No & 7 & 49 & Yes & No & 56 & \\
\hline$G$ & No & 7 & 84 & Yes & No & 91 & \\
\hline $\mathrm{H}$ & No & 28 & No & Yes & No & 28 & \multirow{2}{*}{$\begin{array}{l}\text { (IV) Use of PVC film } \\
\text { membrane; }\end{array}$} \\
\hline I & No & 28 & 28 & Yes & No & 56 & \\
\hline J & No & 7 & No & No & No & 7 & \multirow{3}{*}{$\begin{array}{l}\text { (V) Days with superficialal } \\
\text { Paraffin membrane } \\
\text { in laboratory }\left(25^{\circ} \mathrm{C}\right) \text {; }\end{array}$} \\
\hline K & No & 28 & No & No & No & 28 & \\
\hline L & No & 28 & 28 & No & No & 56 & \\
\hline$M$ & No & No & No & No & Yes & 7 & \multirow{3}{*}{$\begin{array}{l}\text { (VI) Day of Test } \\
\text { (modulus } \\
\text { of rupture). }\end{array}$} \\
\hline $\mathrm{N}$ & No & No & No & No & Yes & 28 & \\
\hline 0 & No & No & No & No & Yes & 91 & \\
\hline
\end{tabular}

were kept in water tanks until the day of the strength tests. The following possible procedures were applied, depending on the curing method (from A to O) adopted: (I) Immersion in water tank (in days, at constant $20^{\circ} \mathrm{C}$ ) ; (II) Moisture chamber (in I days, at constant $100 \%$ moisture); (III) Days exposed in laboratory before tests (at constant $25^{\circ} \mathrm{C}$ ); (IV) Use of PVC film membrane ; (V) Days with superficial Paraffin membrane in laboratory $\left(25^{\circ} \mathrm{C}\right)$; (VI) Day of Test (modulus of rupture).

HSC specimens wrapped in PVC film are shown in Figure 1. Wrap-

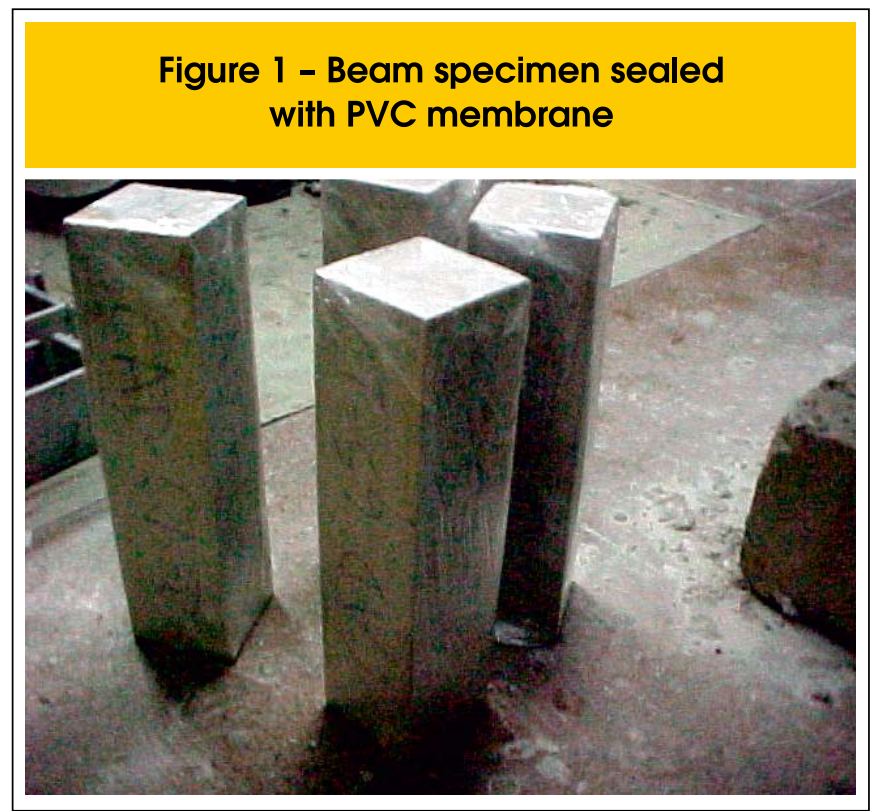

ping was done immediately after their extraction from the mold and the plastic film was kept until the date of the test; this procedure was adopted so as to avoid the loss of moisture from the specimen to the curing environment and vice-versa. Specimens led to cure only by paraffin membrane (rate of $0.4 \mathrm{~L} / \mathrm{m}^{2}$ ) were kept in the mold until the rupture date (Figure 2); paraffin membrane curing was chosen due to the fact that it is the most common field curing method for pavements. Three concrete beams were prepared for each curing procedure in order to avoid misleading tests or specimens.

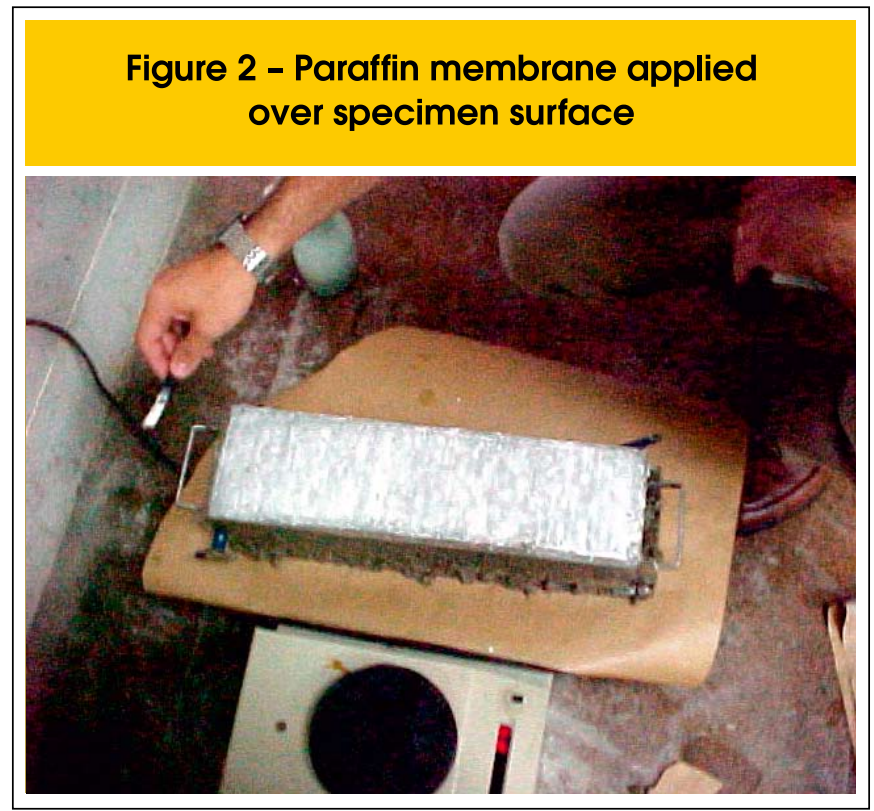


Table 3 - Statistics of flexural strengths for each type of curing

\begin{tabular}{|cccc|} 
Curing Method & $\begin{array}{c}\text { Average filexural } \\
\text { strength }\left(\mathbf{N} / \mathrm{mm}^{2}\right)\end{array}$ & $\begin{array}{c}\text { Standard deviation } \\
\left(\mathbf{N} / \mathbf{m m}^{2}\right)\end{array}$ & $\begin{array}{c}\text { Coefficient of } \\
\text { variation (\%) }\end{array}$ \\
A & 6.50 & 0.22 & 3.3 \\
B & 5.97 & 0.38 & 6.3 \\
C & 7.27 & 0.09 & 1.3 \\
D & 6.00 & 0.24 & 4.1 \\
E & 5.03 & 0.17 & 3.4 \\
F & 5.77 & 0.25 & 4.3 \\
G & 6.00 & 0.24 & 4.1 \\
H & 6.73 & 0.09 & 1.4 \\
I & 5.23 & 0.09 & 1.8 \\
J & 5.75 & 0.45 & 7.8 \\
K & 7.05 & 0.05 & 0.7 \\
L & 5.60 & 0 & 0 \\
M & 5.33 & 0.17 & 3.2 \\
N & 5.70 & 0.08 & 1.4 \\
O & 5.70 & 0.45 & 8.0 \\
\hline
\end{tabular}

Aiming to explain saturation effects on both CC and HSC concretes, permeability tests were carried out using the method suggested by the Cement Industry Research Institute in Germany [4]. Test samples were extracted from concrete specimens and then immersed in water for 7 days prior to air permeability tests.

Following the curing plans established in Table 2, third-point loading tests were carried out on the beams to define concrete flexural strength. Loading rate on the bending tests was $0.046 \mathrm{kN} / \mathrm{s}$.

\section{Results and Analysis}

Table 3 shows results of flexural strengths for each kind of curing procedure adopted for HSC concrete specimens. As one can see, results point out a loss of 8 to $22 \%$ on the flexural strength for all dry HSC specimens when compared to the saturated specimens at the date of the test. Such behavior was the same for dry and saturated specimens at 28 days (cases $B$ and $C$ ) and for saturated 7-day and dry 28-day specimens (cases A and B). Increasing in resistance due to saturation was surprising, since the contrary was expected for saturated specimens.

Specimens tested in dry condition at 56 and 91 days (cases F, G, $I$ and $L$ ) presented lower strength than the saturated concrete at 28 days (cases $\mathrm{C}, \mathrm{H}$ and $\mathrm{K}$ ); all results reinforce the role of water saturation in the increase of strength for HSC. On the other hand, specimens cured only by paraffin membrane protection, a curing product often employed in construction sites, developed low strengths, which is an unsafe result for pavement performance when mix design specifies curing by tank immersion..

From results it can be seen that all wet curing processes resulted in similar strength after 7 days (cases $A, D$ and $J$ ) whatever the procedure; it is thus inferred that the use of PVC film is expendable. Strengths of specimens kept 28 days in water immersion as well as in moist chamber, with or without PVC film, are quite similar, inde- pendently of the curing procedure and whether PVC film is used or not. Figure 3 shows graphically the results of the the comparison. Results showed that HSC flexural strength is influenced by water saturation. It becomes clear by the comparison between long-term results presented in Table 4. For this investigation, HSC beams were kept in tanks up to 7 days and then they were wrapped with PVC film, keeping the membrane for 180 days. After the curing procedure, dry tests were performed and 7-day pre-saturated specimens were also prepared to be tested. Conventional concrete remained 28 days under water and then in laboratory conditions without PVC film up to 180 days; both dry beams and 7-day pre-saturated beams were tested on the same date.

Table 4 shows that HSC behaves, from the perspective of flexural strength, differently from $\mathrm{CC}$. While in $\mathrm{CC}$ a small decrease on strength occurs when the beams are saturated, for HSC there is a $20 \%$ increase on the flexural strength due to saturation, showing that, also in the long-term behavior, HSC presents greater flexural strength when saturated.

Finally, a long-term test was accomplished with HSC beams that were first cured for 180 days in laboratory condition (with PVC film), then were kept for 7 days under water without PVC, and finally were dried for 7 days in laboratory condition (without PVC). Results for flexural strength after that procedure are shown in Table 5, proving, once more, that the effect of saturation disappeared after specimens were dry.

Results of air permeability tests were considered as an attempt to better understand the aforementioned results about saturation effects. Results shown in Figure 4 point out that permeability of conventional concrete is much higher (approximately three times) than HSC. In fact, permeability is connected to the pore structure of the material, and one could expect a less porous microstructure for HSC as a result of the higher cement content within the mixture, more fine early strength cement as well as due to the pres- 


\section{Figure 3 - Flexural strength of beams according to the curing procedure}

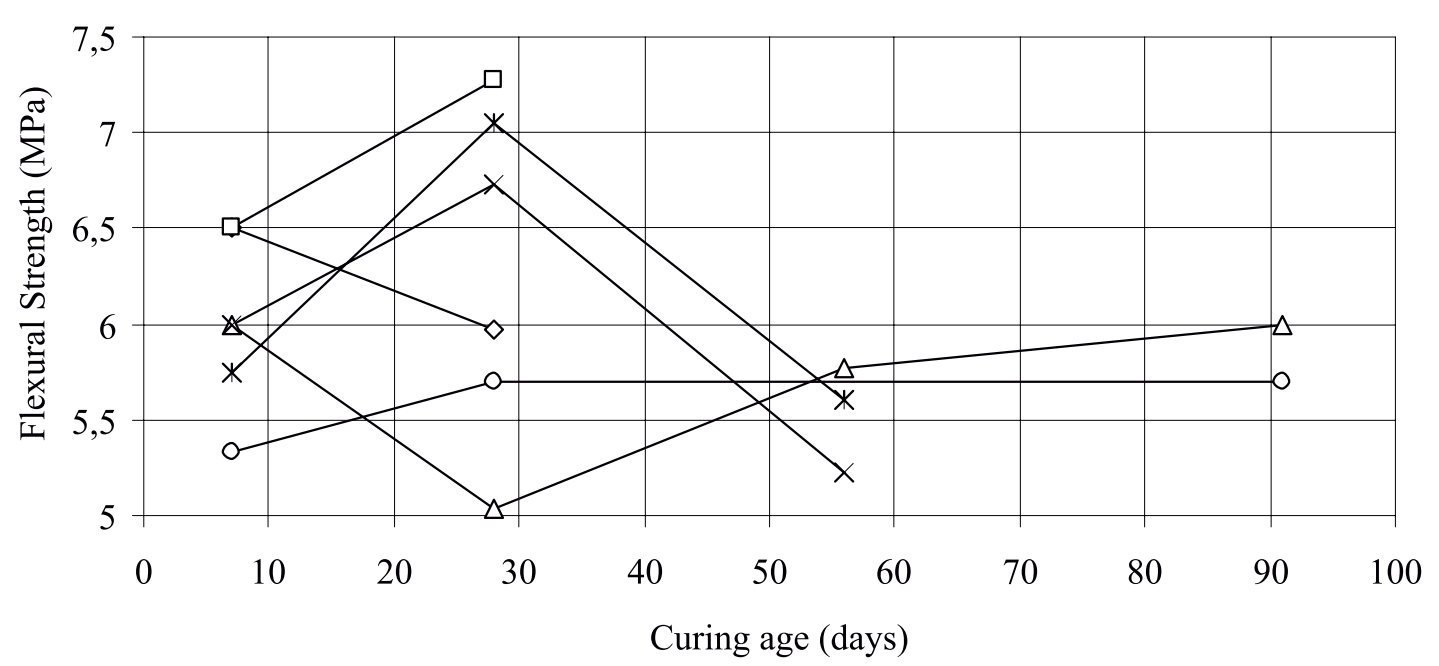

$$
\begin{array}{lll}
\rightarrow \text { Methods A and B } & \rightarrow \text { Methods A and C } & \triangle \text { Methods D, E, F and G } \\
\rightarrow \text { Methods D, H and I } & \rightarrow \text { Methods J, K and L } & - \text { Methods M, N and O }
\end{array}
$$

ence of silica fume, since this latter induces less permeability for the concrete [5]. Note that when air permeability decreases, air pressure increases. From the results it is possible to foresee that HSC should be less porous, presenting a less dense porosity chain within its structure; moreover, permeability of HSC is, in practice, not affected by pressure during tests.

Permeability tests enabled the achievement of a possible explanation for the observed phenomenon of increasing flexural strength due to saturation of HSC: the low porosity within HSC, due to the greater amount of hydration crystals resulting from fine cement and silica fume reactions, not only quantitatively but also in terms of little pore dimensions, contributes to a greater difficulty for water expulsion from the material during a quick (not drained) bending test.

Therefore, whenever HSC is saturated (which is uncommon when pavement is in service), negative suction stresses arise within pore

\section{Table 4 - Long-term flexural strength

\begin{tabular}{|c|c|c|c|c|}
\hline $\begin{array}{l}\text { Type of } \\
\text { PCC }\end{array}$ & $\begin{array}{l}\text { Dry } \\
\text { CC }\end{array}$ & $\begin{array}{c}\text { Saturated } \\
\text { CC }\end{array}$ & $\begin{array}{l}\text { Dry } \\
\text { HSC }\end{array}$ & $\begin{array}{c}\text { Saturated } \\
\text { HSC }\end{array}$ \\
\hline \multirow[t]{3}{*}{ Individual values } & 4.8 & 5.0 & 6.0 & 6.9 \\
\hline & 4.8 & 4.4 & 5.7 & 6.9 \\
\hline & 5.3 & 4.6 & 5.7 & 7.2 \\
\hline Average & 5.0 & 4.7 & 5.8 & 7.0 \\
\hline
\end{tabular} $\left(\mathrm{N} / \mathrm{mm}^{2}\right)$ for concretes (180 days)}

volume boundary, requiring greater stresses to fracture the HSC during the flexural test. Such phenomenon was not verified for the conventional concrete whose porosity chain is denser and pores are greater due to lower amount of hydraulic binders.

In compression, the effect of water saturation on specimens is the reduction of the compressive strength. However, for jointed plain concrete pavements, flexural strength is the key for pavement design and performance since such structures work in bending due to loads and curling effects.

In terms of controlling concrete flexural strength in field and even during the mixture design, it seems to be improper to keep the HSC beams under water or fully saturated since the resulting strengths would be not realistic accordingly.

Besides that, the curing procedure by use of chemical curing film over the concrete surface has been shown to be not as effective as the other procedures, namely, the using of PVC film, in water im-

\section{Table 5 - Long-term ( 180 days) flexural strength $\left(\mathrm{N} / \mathrm{mm}^{2}\right)$ for HSC (dry-saturated-dry)}

\begin{tabular}{ccc|}
\hline Condition of HSC & Dry & Dry-Saturated-Dry \\
\hline Individual values & 6.0 & 6.2 \\
& 6.1 & 6.3 \\
Average & 6.3 & 6.6 \\
& 6.1 & 6.4 \\
\hline
\end{tabular}




\section{Figure 4 - Permeability as function of pressure for concretes}

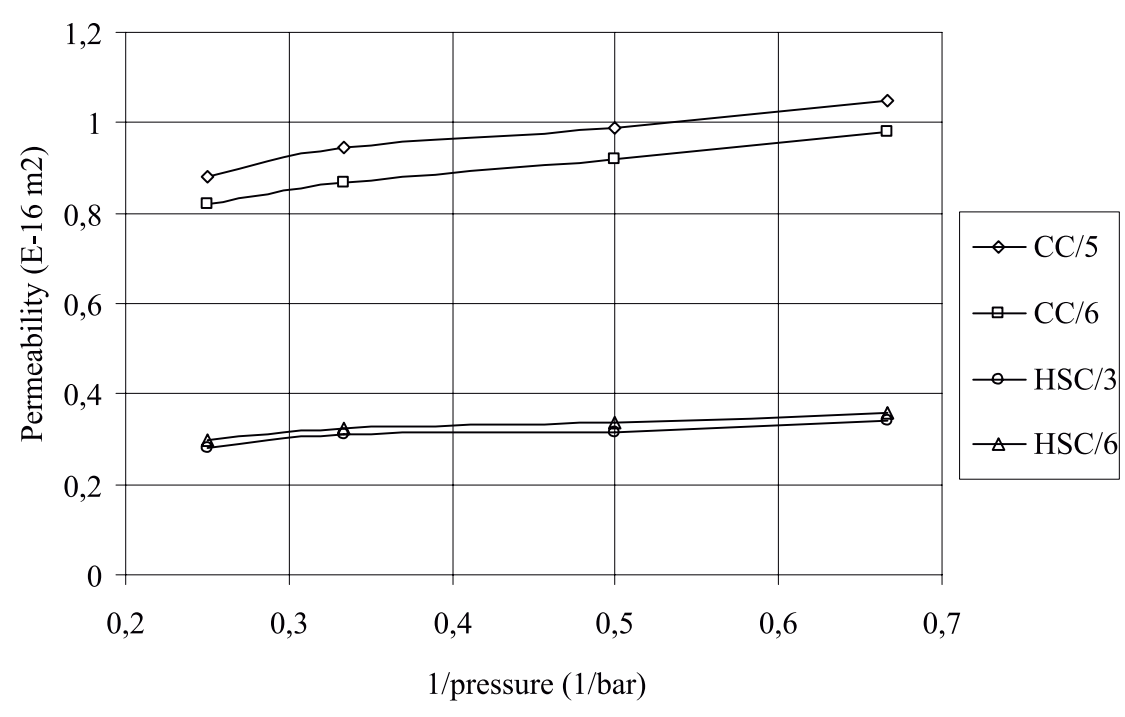

mersion or in moist chamber. Flexural strength fell from 6,5 to 5,3 $\mathrm{MPa}$ at 7 days and from 7,3 to $5,7 \mathrm{MPa}$ at 28 days. These results arise from the inadequacy of such curing process; on the other hand, the saturated procedure is inappropriate to predict field flexural strength in slabs. Therefore, curing conditions in field should be too much better represented by the use of chemical curing film in laboratory.

\section{Concluding Remarks}

HSC is an optional concrete mixture for pavements required to be open to traffic earlier than conventional concrete pavements. Although no specific requirements have been stated in the last years concerning special care for curing such high strength concrete mixtures for mix design or quality control purposes, the laboratorial forensic investigation was able to make it clear the influence of beams saturation on the flexural strength of the specimens.

The investigation showed that concrete mixture design for a pavement project should not be carried out on the basis of saturated specimens results under the risk of overestimating flexural strength in the case of HSC. The study shows that expressive strength increase is achieved when measures are made over saturated specimens. Since pavement structures in airports and highways are not subjected to saturation, the study allows to safely recommending to not controlling HSC strength with specimens kept in green house or immersion tanks due to the unrealistic results for flexural strength.

However, even with lower results obtained for chemical curing in laboratory, it is still open the better procedure for curing HSC for quality control or mixture proportions purposes. Besides that, no new particular recommendation is due to conventional concretes in terms of curing if one considers that the loss of strength due to its saturation was expected.

\section{Acknowledgements}

Authors are indebted to Sao Paulo Research Foundation (FAPESP) and CAPES Foundation for the financial support given for the research.

\section{References}

[01] Tan, K; Gjorv, O. E. Performance of concrete under different curing conditions. Cement and Concrete Research, vol. 26, n. 3, pp. 355-361, 1996.

[02] Ewertson, C.; Petersson, P.E. The influence of curing conditions on the permeability and durability of concrete. Results from a field exposure test. Cement and Concrete Research, vol. 23, pp. 683-692, 1993.

[03] Raithby, K.D.; Galloway, J.W. Effects of moisture condition, age, and rate of loading on fatigue of plain concrete. Proceedings of ABELES Symposium on Fatigue of Concrete, Hollywood, ACI Publication, v. 41, pp. 15-34, 1974.

[04] Gräf, H. and Grube, H. Verfahren zur prüfung der Durchlässigkeite von mörtel und beton gegenüber gasen und wasser. Beton, Helft 5, 1986.

[05] Badawy, M and Honegger, E. Swissmetro - test on air permeability of concrete. Proceedings of the $16^{\text {th }}$ Congress of IABSE, Cd-rom, Lucern, 2002. 